

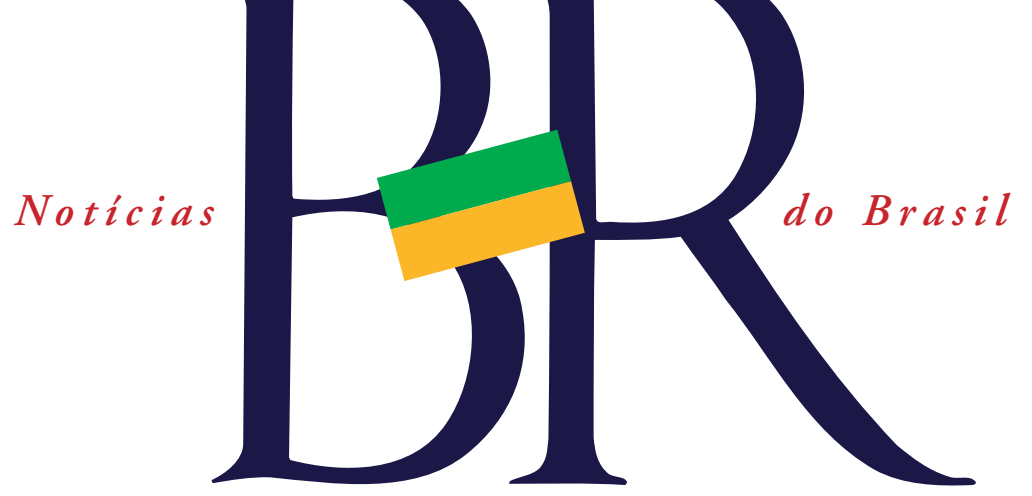

à descoberta de substâncias presentes em animais, como esponjas e moluscos, e em microrganismos (fungos e bactérias), que possam ser úteis para o desenvolvimento de novos medicamentos. Já se sabe que algumas delas têm a capacidade de matar os parasitas que causam a leishmaniose e a doença de Chagas. 0 grupo também estuda os processos pelos quais essas substâncias são formadas pelos organismos de origem (biossíntese), principalmente em bactérias e fungos marinhos. "Estudamos a maneira pela qual essas substâncias são 'construídas' dentro das células desses microrganismos, através de regulação gênica e várias reações controladas por enzimas. Muitos desses processos de biossíntese envolvem a participação de enzimas bastante peculiares, que podem ser produzidas em maior escala e utilizadas em processos biotecnológicos. A partir desse conhecimento, é possível 'imitar' esses sistemas para produzir essas enzimas em escala industrial e utilizá-las para diferentes finalidades tanto na indústria farmacêutica como na de alimentos, cosméticos e agroquímica", destaca Berlinck.

Patricia Piacentini

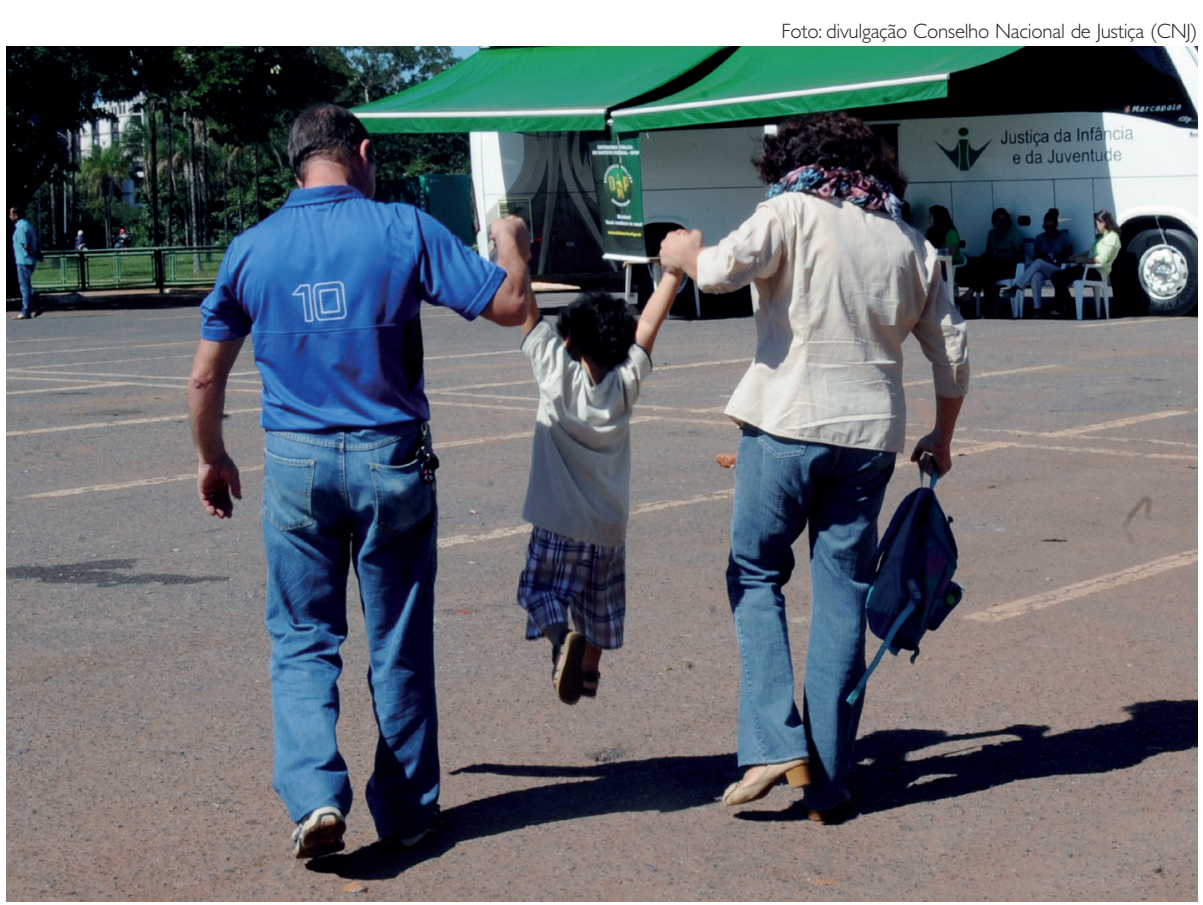

Redução dos prazos de adoção deve ser votada este ano pelo Congresso

DIREITOS HUMANOS

\section{Novas regras para adoção: avanço ou retrocesso?}

Segundo dados do Cadastro Nacional de Crianças Acolhidas (CNCA), do Conselho Nacional de Justiça $(\mathrm{CNJ})$, hoje no Brasil há mais de 46 mil crianças e adolescentes em instituições de acolhimento. Desse número, de acordo com o Cadastro Nacional de Adoção (CNA), apenas sete mil estão aptas para adoção. Por outro lado, o mesmo cadastro mostra que há mais de 37 mil pessoas interessadas em adotar. Esses números expõem o descompasso entre perfis de pretendentes e os das crianças e adolescentes cadastrados. Por exem- plo, $55 \%$ dos pretendentes preferem crianças de zero a três anos de idade, de acordo com o CNA.

Considerando a necessidade de minimizar esse desencontro e acelerar os processos de adoção no Brasil, o Ministério da Justiça e Cidadania propôs um conjunto de medidas para alterar a legislação brasileira para adoção de crianças e adolescentes. As alterações colocadas em debate pelo ministério estão voltadas, sobretudo, para a definição de prazos para os procedimentos. No caso da entrega voluntária, a proposta da pasta é que 